\title{
Perbandingan Tingkat Pemahaman Mahasiswa STMIK STIKOM Indonesia pada Metoda Eliminasi Gauss dan Metoda Cramer pada Penyelesaian Sistem Persamaan Linier
}

\author{
Nia Maharani \\ STMIK STIKOM Indonesia, Bali \\ Email: maharani.nst@gmail.com
}

DOI: https://doi.org/10.33369/pendipa.4.2.66-73

\begin{abstract}
[Comparison of student Understanding level of STMIK STIKOM INDONESIA in the Sarrus Method and the Cramer Method in the Completion of a Linear Equation System] This study discusses the level of understanding of 40 student samples STIMIK STIKOM INDONESIA in the material Completion of the Linear Equation System for the ordo $3 \times 3$ using the Gauss Elimination and Cramer Rules. The basic principle of the two methods is to use matrix operations. From the results of previous studies, the Gauss Elimination method is more effective (completion steps and the number of arithmetic operations less, and the speed and accuracy are better) than the Cramer Rules. The procedure of this study was that 40 student samples were given one case and then resolved using both methods with 10 people choosing the Gaussian method first as a method that is easier to understand and the remaining 30 people choosing the Cramer Rules. This shows that although the concept of the Gauss Elimination method is more effective than the Cramer Rule, students prove to understand more about the Cramer Rule than the Gauss Elimination.
\end{abstract}

Keywords: Gauss Elimination, Cramer rules, system of linear equation.

\begin{abstract}
ABSTRAK
Penelitian ini membahas tentang tingkat pemahaman dari 40 sampel mahasiswa STMIK STIKOM Indonesia pada materi Penyelesaian Sistem Persamaan Linear untuk ordo 3 x 3 menggunakan Eliminasi Gauss dan Aturan Cramer. Prinsip dasar dari kedua metoda tersebut adalah penggunaan operasi matriks. Dari hasil penelitian-penelitian sebelumnya diperoleh bahwa metoda Eliminasi Gauss lebih efektif (langkah penyelesaian dan jumlah operasi aritmatikanya lebih sedikit, serta kecepatan dan ketepatannya lebih baik) dibandingkan Aturan Cramer. Prosedur penelitian ini melibatkan 40 sampel mahasiswa yang diberikan satu kasus lalu menyelesaikannya dengan kedua metoda tersebut dengan 10 orang memilih metoda Gaussian terlebih dahulu sebagai metoda yang lebih mudah dipahami dan 30 orang sisanya memilih Aturan Cramer. Hal ini menunjukkan bahwa meskipun secara konsep metoda Eliminasi Gauss lebih efektif dibanding dengan Aturan Cramer, tetapi mahasiswa ternyata lebih memahami Aturan Cramer dibandingkan Eliminasi Gauss dalam menyelesaikan sistem persamaan linier.
\end{abstract}

Kata kunci: Eliminasi Gauss, aturan Cramer, sisterm persamaan linier.

\section{PENDAHULUAN}

Latar Belakang

Teori Aljabar merupakan salah satu cabang dari Matematika. Matematika adalah mata kuliah wajib diikuti oleh semua mahasiswa S1 dari jurusan Sistem Komputer di STMIK STIKOM Indonesia. Matematika berperan sebagai ilmu dasar mempunyai andil dalam pemgembangan ilmu-ilmu lain dan melatih berfikir logis dan matematis serta berada di depan dalam perkembangan teknologi yang dibutuhkan oleh Sistem Komputer. Salah satu pokok bahasan yang terkandung dalam materi Aljabar Linier adalah Persamaan Linier dan Sistem Persamaan Linier. Persamaan Linier adalah suatu persamaan yang pada saat digambarkan kurvanya berupa garis 
lurus, sedangkan Sistem Persamaan Linier adalah suatu sistem yang didalamnya terdiri minimal 2 persamaan linier. Persamaan linier dapat terdiri dari $m$ persamaan dan $n$ variabel (Purnama, 2018). Penyelesaian bentuk ini dapat diselesaikan melalui matriks. Matriks adalah sekumpulan bilangan yang disusun secara baris dan kolom dan ditempatkan pada kurung biasa atau kurung siku.

Masalah yang sering muncul dalam mencari penyelesaian sistem persamaan linier (SPL) biasanya berhubungan dengan ukuran matriks, semakin besar ukuran matriks semakin rumit pula perhitungannya, sehingga dibutuhkan metoda yang tepat. Pada topik SPL dimiliki SPL didasarkan pada bentuk matriks elementer tereduksi umumnya mahasiswa mengalami kesulitan dalam mengidentifikasi jenis solusi SPL didasarkan pada bentuk matriks elementer tereduksi. Dalam menganalisis jenis solusi yang dimiliki SPL berdasarkan matriks elementer tereduksi dibutuhkan kemampuan mahasiswa dalam membaca simbol dan notasi matematis. Kemampuan mahasiswa dalam menginterpretasi ekspresi matematis akan mempengaruhi tingkat pemahaman matematisnya. Selain itu juga diperlukan kemampuan mahasiswa dalam Menyusun pola matematis berdasarkan ekspresi matematis. Dalam hal ini kemampuan penalaran matematis juga mempengaruhi kemampua mahasiswa dalam memahami suatu konsep atau topik matematis secara komprehensif. (Rosita, Laelasari, Noto, 2014). Beberapa metoda yang digunakan untuk penyelesaian Sistem Persamaan Linier adalah Metoda Eliminasi Gauss, Eliminasi Gauss Jordan, Metoda Cramer, Metoda Invers Matriks, Dekomposisi LU (faktorisasi segitiga atas-bawah) dan Dekomposisi Crout. (Anton, 2004).

Pada penelitian ini penulis menggunakan metoda Eliminasi Gauss dan Metoda Cramer. Berdasarkan penelitian sebelumnya yaitu Kasrina Kamaluddin dengan judul "Analisis Metoda Eliminasi Gauss dan Aturan Cramer dalam Menyelesaikan Sistem Persamaan Linier serta Aplikasinya. Pada penelitian tersebut diperoleh kesimpulan bahwa metoda Eliminasi Gauss lebih efektif (langkah penyelesaian dan jumlah operasi aritmatikanya lebih sedikit, serta kecepatan dan ketepatannya lebih baik) dibanding Aturan Cramer bahkan untuk matriks berukuran besar 6 persamaan dan 6 variabel. Penelitian lain yang relevan berjudul "Analisis Kemampuan Pemahaman Matematis Pada Mata Kuliah Aljabar Elementer" dengan hasil mahasiswa dapat, dalam menggunakan, memanfaatkan dan memilih prosedur atau operasi dalam Metoda Cramer adalah $83 \%$ tercapai sedangkan mahasiswa mampu mengaplikasikan konsep atau algoritma pemecahan masalah dalam menyelesaikan SPL menggunakan Gaussian adalah $53 \%$ tercapai. (Ruswana, 2019). Hasil penelitian lain menyatakan bahwa masih banyak mahasiswa yang melakukan kesalahan dalam menyelesaikan SPL menggunakan OBE. Umtuk jenis kesalahan mahasiswa yang berkaitan dengan konsep dasar sebesar 28,13\%, kesalahan yang berkaitan dengan kesalahan hitung sebesar 40,63\%, kesalahan penulisan dan penggunaan tanda sebesar 21,88\%, kesalahan dengan menjawab sembarang sebesar 25\% (Nawafilah, 2019).

Hasil-hasil penelitian inilah yang memberikan motivasi kepada penulis untuk meneliti lebih lanjut tentang bagaimana tingkat pemahaman mahasiswa terhadap kedua metoda tersebut pada 3 persamaan dan 3 variabel pada penyelesaian Sistem Persamaan Linier meskipun secara hasil riset pustaka menunjukkan metoda Gauss lebih efektif dibanding Aturan Cramer (Kamaluddin, 2015).Tapi apakah secara praktek mahasiswa lebih memahami konsep penyelesaian Eliminasi Gauss atau Metoda Cramer atau bahkan keduanya.

\section{Rumusan Masalah}

Dalam penelitian ini penulis merumuskan masalah meskipun Aturan Gauss lebih efektif dibandingkan dengan Aturan Cramer, tapi secara praktek metoda yang mana lebih mudah dipahami oleh mahasiswa dari kedua metoda tersebut.

\section{Tujuan}

Tujuan penulisan ini adalah untuk mengetahui dari kedua metoda Eliminasi Gauss dan Aturan Cramer mana yang mudah dipahami oleh mahasiswa dalam menyelesaikan Sistem Persamaan Linier.

Batasan Masalah

Agar pembahasan ini nantinya tidak meluas, maka penulis perlu memberikan batasan masalah mengenai matriks yang diteliti yaitu : 
1.Matriks berukuran 3 x 3 yang akan diselesaikan dengan Metoda Eliminasi Gauss dan Aturan Cramer.

2. Sistem Persamaan Linier yang digunakan yaitu sistem persamaan linier tak homogen dan konsisten.

\section{TINJAUAN PUSTAKA}

Matriks

Matriks adalah susunan sekelompok bilangan didalam suatu jajaran yang berbentuk persegi panjang dan diatur berdasarkan baris dan kolom yang kemudian diletakkan antara 2 tanda kurung. Tanda kurung yang dipakai untuk mengapit susunan anggota matriks tersebut bisa berupa tanda kurung biasa atau kurung siku. (Kusumawati, 2009).

Penamaan suatu matriks biasanya dinyatakan dengan huruf kapital, misalnya matriks A, B, C, $\mathrm{D}, \ldots$, dan seterusnya. Dalam matriks dikenal dengan istilah ordo. Ordo matriks adalah bilangan yang menunjukkan banyaknya baris $(m)$ dan banyaknya kolom $(n)$ pada matriks.

Contoh : Suatu matrik A dengan $m$ baris dan $n$ kolom ditulis :

$$
A_{m \times n}=\left[\begin{array}{cccc}
a_{11} & a_{12} & \cdots & a_{1 n} \\
a_{21} & a_{22} & \cdots & a_{2 n} \\
\cdots & \cdots & \cdots & \cdots \\
a_{m 1} & a_{m 2} & \cdots & a_{m n}
\end{array}\right]
$$

Contoh Matriks :

Penjumlahan dan Pengurangan Matriks

Dua matriks atau lebih, dapat dijumlakan hanya jika memiliki ordo yang sama. Penjumlahan dilakukan dengan menjumlahkan elemen-elemen yang berposisi sama. Contoh:

Jika

$$
A=\left(\begin{array}{ll}
1 & 4 \\
2 & 5 \\
3 & 6
\end{array}\right) \text { dan } B=\left(\begin{array}{ll}
3 & 6 \\
4 & 7 \\
5 & 8
\end{array}\right)
$$

maka:

$$
\begin{aligned}
& A+B=\left(\begin{array}{ll}
1 & 4 \\
2 & 5 \\
3 & 6
\end{array}\right)+\left(\begin{array}{ll}
3 & 6 \\
4 & 7 \\
5 & 8
\end{array}\right) \\
& =\left(\begin{array}{ll}
1+3 & 4+6 \\
2+4 & 5+7 \\
3+5 & 6+8
\end{array}\right)=\left(\begin{array}{ll}
4 & 10 \\
6 & 12 \\
8 & 14
\end{array}\right)
\end{aligned}
$$

Sama halnya dengan penjumlahan, pengurangan dapat dilakukan hanya jika dua matriks atau lebih, memiliki ordo yang sama. Pengurangan dilakukan terhadap elemen-elemen yang berposisi sama.

Contoh:

Jika $A=\left(\begin{array}{ll}1 & 4 \\ 2 & 5 \\ 3 & 6\end{array}\right)$ dan $B=\left(\begin{array}{ll}3 & 6 \\ 4 & 7 \\ 5 & 8\end{array}\right)$,

maka:

$\mathrm{B}-\mathrm{A}=\left(\begin{array}{ll}3 & 6 \\ 4 & 7 \\ 5 & 8\end{array}\right)-\left(\begin{array}{ll}1 & 4 \\ 2 & 5 \\ 3 & 6\end{array}\right)$

$=\left(\begin{array}{ll}3-1 & 6-4 \\ 4-2 & 7-5 \\ 5-2 & 8-6\end{array}\right)=\left(\begin{array}{ll}2 & 2 \\ 2 & 2 \\ 2 & 2\end{array}\right)$

Sifat dari penjumlahan dan pengurangan matriks:

- $\mathrm{A}+\mathrm{B}=\mathrm{B}+\mathrm{A}$

- $(\mathrm{A}+\mathrm{B})+\mathrm{C}=\mathrm{A}+(\mathrm{B}+\mathrm{C})$

- $\mathrm{A}-\mathrm{B} \neq \mathrm{B}-\mathrm{A}$

\section{Perkalian Matriks}

Matriks dapat dikalikan dengan sebuah bilangan bulat atau dengan matriks lain. Kedua perkalian tersebut memiliki syarat-syarat masingmasing.

Perkalian Matriks dengan Bilangan Bulat.

Suatu matriks dapat dikalikan dengan bilangan bulat, maka hasil perkalian tersebut berupa matriks dengan elemen-elemennya yang merupakan hasil kali antara bilangan dan elemenelemen matriks tersebut. Jika matriks A dikali dengan bilangan $r$, maka $r . A=\left(r . a_{\mathrm{ij}}\right)$. Contoh:

Jika $\mathrm{A}=\left(\begin{array}{ll}1 & 4 \\ 2 & 5 \\ 3 & 6\end{array}\right)$ dan bilangan $\mathrm{r}=2$, maka :

r.A $=2 .\left(\begin{array}{ll}1 & 4 \\ 2 & 5 \\ 3 & 6\end{array}\right)=\left(\begin{array}{ll}2.1 & 2.4 \\ 2.2 & 2.4 \\ 2.3 & 2.6\end{array}\right)=\left(\begin{array}{cc}2 & 8 \\ 4 & 10 \\ 6 & 12\end{array}\right)$

Perkalian matriks dengan bilangan bulat dikombinasikan dengan penjumlahan atau pengurangan matriks dapat dilakukan pada matriks dengan ordo sama. Berikut sifat-sifat perkaliannya:

- $r(\mathrm{~A}+\mathrm{B})=\mathrm{rA}+\mathrm{rB}$

- $r(A-B)=r A-r B$

\section{Perkalian Dua Matriks}

Perkalian antara dua matriks yaitu matriks A dan B, dapat dilakukan jika jumlah kolom A sama dengan jumlah baris $B$. Perkalian tersebut menghasilkan suatu matriks dengan jumlah baris 
sama dengan matriks A dan jumlah saman dengan matriks $\mathrm{B}$, sehingga:

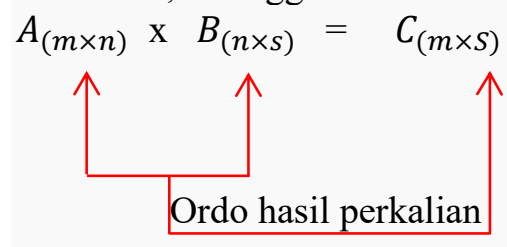

Elemen-elemen matriks $C_{(m \times s)}$ merupakan penjumlahan dari hasil kali elemen-elemen baris ke-i matriks A dengan kolom ke-j matiks B. Berikut skemanya:

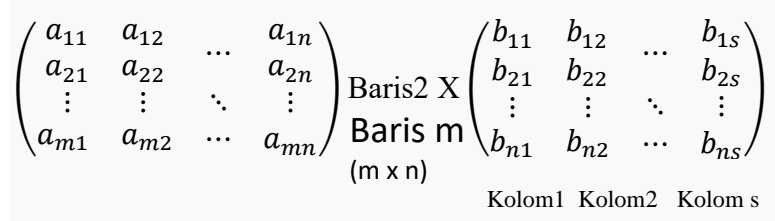$$
\text { Baris } 1
$$

Misalkan matriks A memiliki ordo (3 x 4) dan matriks $\mathrm{B}$ memiliki ordo $(4 \times 2)$, maka matriks $\mathrm{C}$ memiliki ordo $(3 \times 2)$. Elemen $C$ pada baris ke-2 dan kolom ke-2 atau $a_{22}$ diperoleh dari jumlah hasil perkalian elemen-elemen baris ke-2 matriks A dan kolom ke 2 matriks B. Contoh:

$A=\left(\begin{array}{llll}2 & 1 & 4 & 3 \\ 2 & 5 & 1 & 2 \\ 1 & 3 & 2 & 2\end{array}\right)$ dan $B=\left(\begin{array}{ll}1 & 3 \\ 3 & 2 \\ 2 & 5 \\ 1 & 4\end{array}\right)$

maka:

$A \cdot B=C=\left(\begin{array}{llll}2 & 1 & 4 & 3 \\ 2 & 5 & 1 & 2 \\ 1 & 3 & 2 & 2\end{array}\right) \cdot\left(\begin{array}{ll}1 & 3 \\ 3 & 2 \\ 2 & 5 \\ 1 & 4\end{array}\right)$

$\mathrm{C}=\left(\begin{array}{ll}(2.1+1.3+4.2+3.1) & (2.3+1.2+4.5+3.4) \\ (2.1+5.3+1.2+2.1) & (2.3+5.2+1.5+2.4) \\ (1.1+3.3+2.2+2.1) & (1.3+3.2+2.5+2.4)\end{array}\right)$

$\mathrm{C}=\left(\begin{array}{ll}16 & 40 \\ 21 & 29 \\ 16 & 27\end{array}\right)$

Jenis-jenis matriks

Jenis-jenis matriks berdasarkan pola elemennya (Pudjiasti, 2006).

1. Matriks identitas adalah matriks persegi yang elemen-elemen diagonal utamanya adalah 1, sedangkan yang lainnya nol.

$$
\mathrm{A}=\left[\begin{array}{ll}
1 & 0 \\
0 & 1
\end{array}\right]
$$

$$
\mathrm{B}=\left[\begin{array}{lll}
1 & 0 & 0 \\
0 & 1 & 0 \\
0 & 0 & 1
\end{array}\right]
$$

2. Matriks nol adalah matriks yang semua elemennya nol.

$$
\begin{aligned}
& A=\left[\begin{array}{ll}
0 & 0 \\
0 & 0
\end{array}\right] \\
& B=\left[\begin{array}{lll}
0 & 0 & 0 \\
0 & 0 & 0 \\
0 & 0 & 0
\end{array}\right]
\end{aligned}
$$

3. Matriks skalar adalah matriks yang elemen-elemen diagonal utamanya sama, sedangkan elemen lainnya nol.

$$
\begin{aligned}
& A=\left[\begin{array}{ll}
2 & 0 \\
0 & 2
\end{array}\right] \\
& B=\left[\begin{array}{lll}
2 & 0 & 0 \\
0 & 2 & 0 \\
0 & 0 & 2
\end{array}\right]
\end{aligned}
$$

4. Matriks diagonal adalah matriks yang elemen-elemen di luar diagonal utamanya nol.

$$
\begin{aligned}
& A=\left[\begin{array}{ll}
3 & 0 \\
0 & 2
\end{array}\right] \\
& B=\left[\begin{array}{lll}
1 & 0 & 0 \\
0 & 2 & 0 \\
0 & 0 & 3
\end{array}\right]
\end{aligned}
$$

5. Matriks segitiga atas adalah matriks persegi yang elemen-elemen di bawah diagonal utamanya nol.

$$
\begin{aligned}
& A=\left[\begin{array}{ll}
2 & 1 \\
0 & 2
\end{array}\right] \\
& B=\left[\begin{array}{lll}
1 & 2 & 3 \\
0 & 4 & 5 \\
0 & 0 & 6
\end{array}\right]
\end{aligned}
$$

6. Matriks segitiga bawah adalah matriks persegi yang elemen-elemen di atas diagonal utamanya nol.

$$
\begin{aligned}
& A=\left[\begin{array}{ll}
2 & 0 \\
1 & 2
\end{array}\right] \\
& B=\left[\begin{array}{lll}
1 & 0 & 0 \\
2 & 3 & 0 \\
4 & 5 & 6
\end{array}\right]
\end{aligned}
$$


7. Matriks simetri adalah matriks persegi yang elemen-elemen di atas diagonal utamanya sama dengan elemen-elemen di bawah diagonal utamanya.

$$
\begin{aligned}
& A=\left[\begin{array}{ll}
2 & 3 \\
3 & 2
\end{array}\right] \\
& B=\left[\begin{array}{lll}
1 & 2 & 4 \\
2 & 3 & 5 \\
4 & 5 & 6
\end{array}\right]
\end{aligned}
$$

Jenis-jenis Matriks berdasarkan jumlah baris dan kolom

1. Matriks baris adalah matriks yang hanya terdiri atas satu baris.

$$
\mathrm{A}=[100]
$$

2. Matriks kolom adalah matriks yang hanya terdiri atas satu kolom.

$$
A=\left[\begin{array}{l}
1 \\
2 \\
3
\end{array}\right]
$$

3. Matriks mendatar adalah matriks yang jumlah kolom lebih banyak dari jumlah baris.

$$
A=\left[\begin{array}{ccccc}
1 & 2 & 3 & 4 & 5 \\
6 & 7 & 8 & 9 & 10
\end{array}\right]
$$

4. Matriks tegak adalah matriks yang memiliki jumlah baris lebih banyak dari jumlah kolom.

$$
A=\left[\begin{array}{ll}
1 & 2 \\
3 & 4 \\
5 & 6 \\
7 & 8
\end{array}\right]
$$

\section{Determinan Matriks}

Determinan adalah suatu bilangan real yang diperoleh dari suatu proses dengan aturan tertentu terhadap matriks bujur sangkar. Determinan dinyatakan sebagai jumlah semua hasil kali dasar bertanda dari matriks bujur sangkarA. (Pudjiastuti, 2006).

Determinan dari sebuah matriks bujur sangkar A, dinotasikan dengan $\operatorname{det}(\mathrm{A})$, atau $|\mathrm{A}|$
Determinan matriks ordo $3 \times 3$ (aturan Sarrus)

Jika $\mathrm{A}=\left(\begin{array}{lll}a & b & c \\ d & e & f \\ g & h & i\end{array}\right)$ maka determinan A adalah:

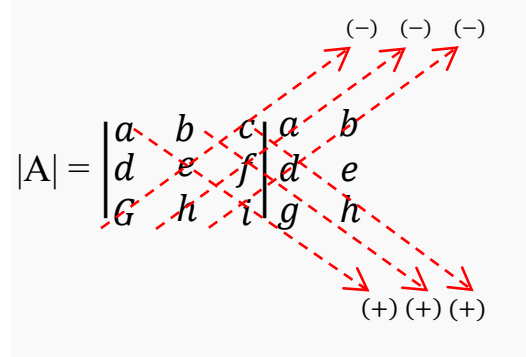

$=$ aei + bfg + cdg - ceg - afh - bdi

\section{Eliminasi Gauss}

Eliminasi Gauss adalah suatu metode untukmengoperasikan nilai-nilai di dalam matriks sehingga menjadi matriks yang lebih sederhana lagi. Dengan melakukan operasi baris sehingga matriks tersebut menjadi matriks yang baris. Ini dapat digunakan sebagai salah satu metode penyelesaian persamaan linear dengan menggunakan matriks. Caranya dengan mengubah persamaan linear tersebut ke dalam matriks teraugmentasi dan mengoperasikannya. Setelah menjadi matriks baris, lakukan substitusi balik untuk mendapatkan nilai dari variabel-variabel tersebut.(Nawafillah, 2009).

\section{Definisi Operasi Baris Elementer}

Operasi Baris Elementer (OBE) merupakan suatu operasi yang diterapkan pada baris suatu matriks. OBE bisa digunakan untuk menentukan invers suatu matriks dan menyelesaikan suatu sistempersamaanlinear(SPL).Operasi Baris Elementer (OBE) adalah salah satu alternatif dalam menyelesaikan suatu bentuk matriks seperti menentukan invers matriks dan penerapan matriks pada sistem persamaan linear menggunakan dua cara yaitu "Eliminasi Gauss" dan "Eliminasi Gauss-Jordan". (Fauziah, 2017). Adapun yang termasuk dalam Operasi Baris Elemeter adalah:

\section{Pertukaran Baris}

Pertukaran Baris merupakan operasi dimana menukar suatu baris dengan baris lainnya pada suatu matriks yang sama. 


\section{Perkalian Suatu Baris Dengan Konstanta Tidak Nol}

Perkalian dengan bilangan real bukan nol, seperti yang di indikasikan oleh namanya, operasi dilakukan dengan mengalikan suatu baris dalam matriks dengan konstanta bilangan real bukan nol.

\section{Penjumlahan Hasil Perkalian Suatu Baris Dengan Konstanta Tidak Nol Dengan Baris Yang Lain \\ Penjumlahan suatu baris dengan baris yang lain, artinya kita mengoperasikan suatu baris terhadap baris lainnya dalam suatu matriks.}

\section{Aturan Cramer}

Aturan Cramer adalah metode untuk menyelesaikan persamaan atau lebih umum mencari solusi dari $\mathrm{n}$ persamaan dan $\mathrm{n}$ bilangan tak diketahui.(Santi, 2017). Rumus yang akan digunakan pada Aturan Cramer (Anton, 2004).

Teorema :

Jika $\mathrm{AX}=\mathrm{B}$ adalah sistem yang terdiri dari $\mathrm{n}$ persamaan linier dalam $\mathrm{n}$ bilangan tak diketahui sehingga $\operatorname{det}(\mathrm{A}) \neq 0$, maka sistem tersebut mempunyai pemecahan yang unik. Pemecahan ini adalah:

$\mathrm{X}_{1}=\frac{\operatorname{det}\left(A_{1}\right)}{\operatorname{det}(A)}, \mathrm{X}_{2}=\frac{\operatorname{det}\left(A_{2}\right)}{\operatorname{det}(A)}, \ldots, \mathrm{X}_{\mathrm{n}}=\frac{\operatorname{det}\left(A_{n}\right)}{\operatorname{det}(A)}$

dimana Aj adalah matriks yang kita dapatkan dengan menggantikan entri-entri dalam kolom kej dari A dengan entri-entri dalam matriks.

$\mathrm{B}=\left[\begin{array}{c}b_{1} \\ b_{2} \\ \vdots \\ b_{3}\end{array}\right]$

\section{METODE PENELITIAN}

\section{Jenis Penelitian}

Penelitan ini menggunakan metoda penelitian Kuasi Eksperimen dengan menggunakan seluruh subjek dalam kelompok belajar (intact grup) untuk diberikan perlakuan (treatment) bukan menggunakan subjek secara acak. Penelitian Eksperimen adalah metoda penelitian yang dilakukan untuk mengetahui pengaruh pemberian suatu instrumen atas perlakuan terhadap subjek penelitian. Lokasi Penelitian adalah di kampus STIMIK STIKOM Indonesia dengan total sampel 40 orang mahasiswa jurusan Sistem Komputer. Waktu Penelitian dimulai dari Maret sampai Juni tahun 2019.

\section{Prosedur Penelitian}

Prosedur penelitian ini adalah 40 sampel mahasiswa diberikan satu kasus lalu menyelesaikan dengan kedua metoda tersebut dengan 10 orang memilih metoda Gaussian terlebih dahulu sebagai metoda yang lebih mudah dipahami dan 30 orang sisanya memilih Aturan Cramer. Hal ini menunjukkan bahwa meskipun secara konsep metoda Eliminasi Gauss lebih efektif (ketepatan, kecepatan dan keakuratan) dibanding dengan Aturan Cramer (Nawafilah,2019) tetapi mahasiswa kemyataan dilapangan lebih memahami Aturan Cramer dibandingkan Eliminasi Gauss.

1. Untuk menyelesaikan Sistem Persamaan Linier dengan Metoda Eliminasi Gauss.

a).Menentukan matriks Adari sistem persamaan linier yang telah ada.

b). Mengecek apakah elemen baris pertama kolom pertama sudah bernilai satu atau

belum. Kalau belum makan gunakan operasi baris elementer pada elemen tersebut.

c). Mengecek apakah baris kedua kolom pertama sudah bernilai nol atau belum jika belum bernilai 0 maka lakukan operasi baris elementer pada elemen tersebut.

d). Mengecek apakah baris ketiga kolom kedua sudah bernilai nol atau belum jika belum

bernilai 0 maka lakukan operasi baris elementer pada elemen tersebut.

e). Mengecek apakah baris ketiga kolom kedua sudah bernilai nol atau belum jika

belum bernilai 0 maka lakukan operasi baris elementer pada elemen tersebut.

f). Apabila matriks sudah dalam bentuk matriks segitiga atas, selanjutnya akan dilakukan

subtitusi balik untuk memperoleh penyelesaian sistem.

2. Untuk menyelesaikan Sistem Persamaan Linier dengan Aturan Cramer.

a). Menentukan matriks $A, x$ dan $B$ dari sistem persamaan linier yang telah ada. 
b). Untuk menentukan matriks $A_{1}$, kolom pertama pada matriks A diganti dengan nilai dari matriks B. Untuk matriks $A_{2}$, kolom kedua pada matriks A diganti dengan nilai dari matriks B. Begitu seterusnya sampai $A_{n}$.

c). Mencari nilai determinan dari matriks $A_{1}, A_{2}$, ..., $\mathrm{A}_{\mathrm{n}}$ dengan metoda Sarrus.

Selanjutnya nilai determinan $\mathrm{A}_{1}$ dan A disubtitusi ke persamaan, untuk mendapatkan

solusi $\mathrm{x}_{1 .}$. Untuk matrisk $\mathrm{A}_{2}$ dan A disubtitusi ke persamaan $\mathrm{x}_{2}=$, untuk mendapatkan

solusi $\mathrm{x}_{2}$. Proses tersebut dilakukan untuk memperoleh solusi sampai $\mathrm{x}_{\mathrm{n}}$ untuk matriks $\mathrm{A}$ d). Nilai x merupakan solusi penyelesaian sistem persamaan linier.

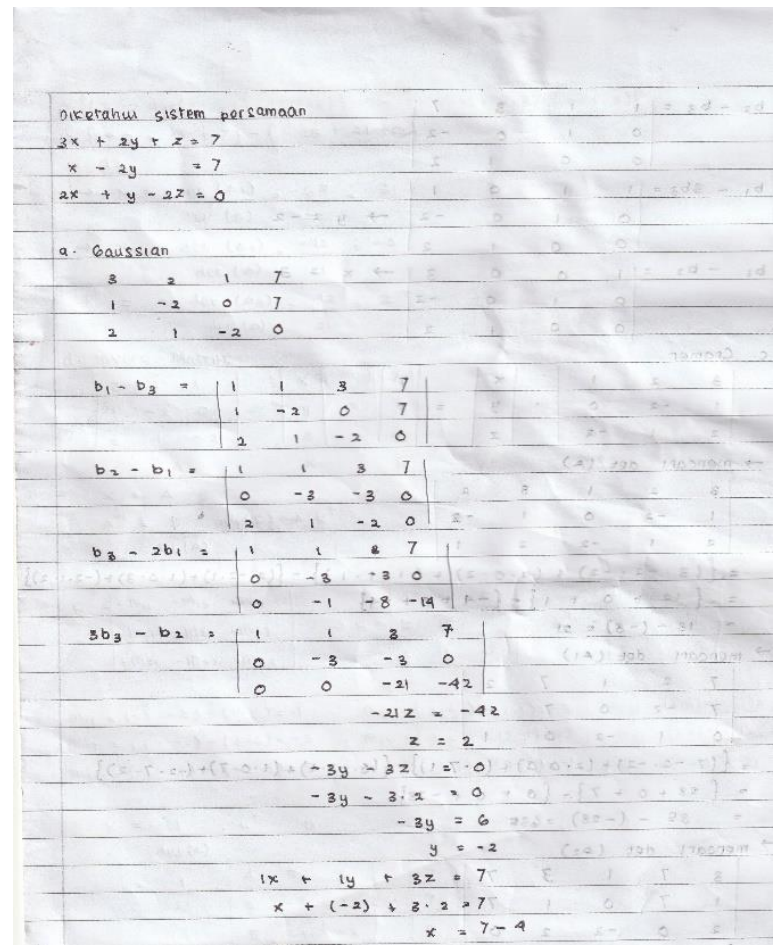

Gambar 1. Contoh Hasil Kerja Mahasiswa Menggunakan Metoda Eliminasi Gauss.

\section{HASIL PENELITIAN DAN PEMBAHASAN}

\section{Hasil Penelitian}

Dari prosedur penelitian yang dilakukan, diperoleh hasil bahwa 10 sampel mahasiswa yang menyelesaikan soal menggunakan urutan :

1. Eliminasi Gauss

\section{Aturan Cramer}

dan 30 orang mahasiswa menyelesaikan sistem persamaan linier dengan urutan sebaliknya yaitu urutan pertama adalah Aturan Cramer disusul Eliminasi Gauss.

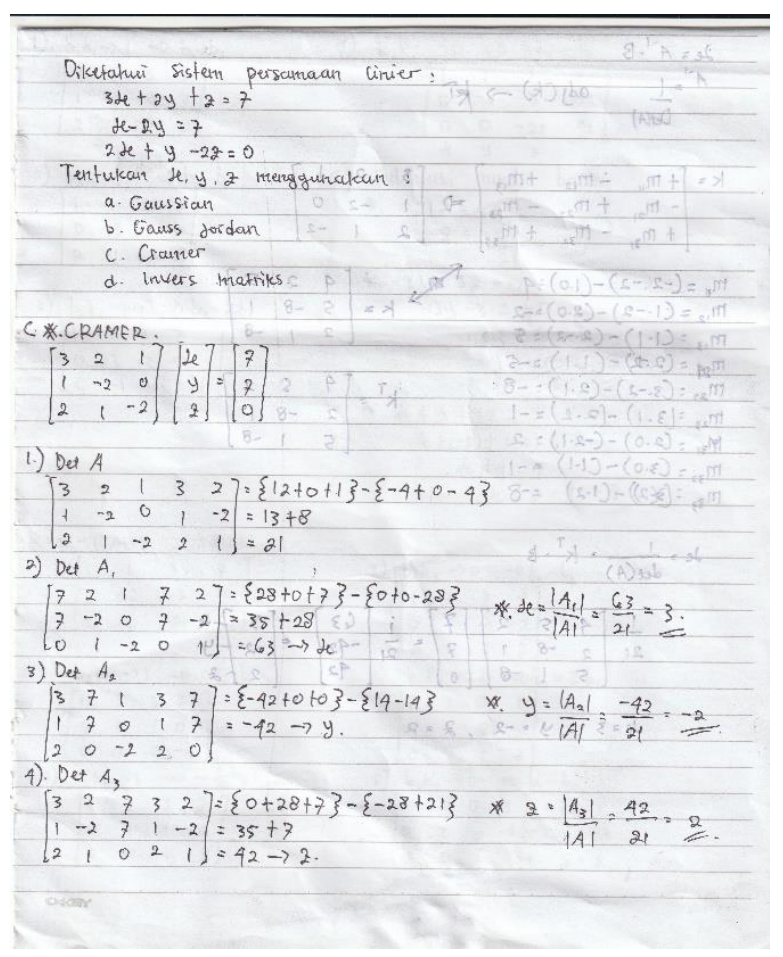

Gambar 2. Contoh Hasil Kerja Mahasiswa Menggunakan Metoda Cramer.

Gambar 1 adalah contoh hasil kerja mahasiswa menggunakan metoda eliminasi Gauss. Berdasarkan penelitian sebelumnya metoda Eliminasi Gauss lebih efektif dibandingkan Aturan Cramer (Ruswana, 2019) seperti terlihat pada Gambar 2. Namun kondisi di lapangan menunjukkan bahwa mahasiswa lebih memilih Aturan Cramer untuk menyelesaikan sistem persamaan linier dibandingkan Eliminasi Gauss. Terbukti bahwa hanya $25 \%$ mahasiswa ( 10 orang ) menyelesaikan soal sistem persamaan linier menggunakan Eliminasi Gauss dan $75 \%$ ( 30 orang ) mahasiswa menyelesaikan dengan Aturan Cramer Hal ini membuktikan bahwa Aturan Cramer lebih mudah dipahami. Berdasarkan hasil wawancara dengan mahasiswa dari sisi langkah penyelesaian menyatakan bahwa meskipun Aturan Cramer mempunyai langkahlangkah yang lebih banyak namun jelas urutan proses penerapannya tanpa memerlukan 
penalaran matematis (Kamaluddin, 2015). Sedangkan Eliminasi Gauss langkah yang ditempuh lebih singkat namun memerlukan penalaran matematis yang kuat dan latihan dalam menyelesaikan tiap-tiap langkahnya, dengan kata lain mahasiswa masih terkendala dalam memilih langkah-langkah yang ada dalam OBE (Operasi Baris Elemeter) untuk mendapatkan matriks segitiga atas sehingga solusi SPL nya berbedabeda. Hasil ini didukung oleh penelitian yang dilakukan pada mahasiswa Unswagati bahwa kesalahan yang dilakukan pada umumnya terletak pada OBE sehingga solusi SPL yang yang diperoleh berbeda-beda (Rosita, Laelasari, Noto, 2014).

\section{KESIMPULAN}

Berdasarkan dari hasil penelitian, dapat disimpulkan bahwa dari metoda pertama yang dipilih bahwa hanya $25 \%$ mahasiswa (10 orang) menyelesaikan soal sistem persamaan linier menggunakan Eliminasi Gauss dan $75 \%$ (30 orang) mahasiswa menyelesaikan dengan Aturan Cramer. Hal ini menunjukkan bahwa meskipun secara konsep metoda Eliminasi Gauss lebih efektif dibanding dengan Aturan Cramer, hal ini dapat dilihat dari banyaknya langkah penyelesaian, kecepatan dan ketepatan dalam menyelesaikan SPL. Sebanyak 40 sampel mahasiswa membuktikan lebih memahami Aturan Cramer dibandingkan Eliminasi Gauss.

\section{DAFTAR PUSTAKA}

Anton, Howard. 2004. Aljabar Linear Elementer. Jakarta: Erlangga.

BSW. Pudjiastuti. 2006. MATRIKS-Teori dan Aplikasi. Yogyakarta: Graha Ilmu.
Fauziah, Wahyuni, W. 2017. Kajian Kesulitan Mahasiswa Dalam Pengoperasian OBE Melalui Metoda TPS Studi Kasus Mata Kuliah ALE Jurnal LEMMA. III (2).

Kasrina K. 2015. Analisis Metode Eliminasi Gauss Dan Aturan Cramer Dalam Menyelesaikan Sistem Persamaan Linear Serta Aplikasinya. Skripsi. Tidak Diterbitkan. Fakultas Sains Dan Teknologi. Universitas Islam Negeri Alauddin: Makassar.

Kusumawati, Ririen. 2009. Aljabar Linear \& Matriks. Malang: UIN-Malang Press

Nawafilah, NQ. 2019. Analisis Kesalahan Mahasiswa Dalam Menyelesaikan Soal Sistem Persamaan Linier Menggunakan Operasi Baris Elementer. Jurnal Pendidikan dan Pembelajaran Reforma. 8(1).

Purnama, A. 2018. Implementasi Aplikasi Penyelesaian Sistem Persamaan Linier Menggunakan Metoda Eliminasi GaussJordan. JOUR.

Rosita, CD, Laelasari, Noto, MS. 2014. Analisis Kemampuan Pemahaman Matematis Mahasiswa Pada Mata Kuliah Aljabar Linier 1. Jurnal Euclid. 1(2),60-136.

Ruswana, AM. 2019. Analisa Kemampuan Pemahaman Matematis Pada Mata Kuliah Aljabar Elementer. Jurnal Cendikia Jurnal Pendidikan Matematika, 3(2), 293-299.

Santi, RCN. 2017. Implementasi Sistem Persamaan Linier Menggunakan Metoda Aturan Cramer. Jurnal Teknologi Informasi DINAMIK, 17(1), 34-38. 